\title{
Sugarcane bagasse as a source of carbon for enzyme production by filamentous fungi
}

\author{
Flaviane Lopes Ferreira ${ }^{1,2}$, Cesar Barretta Dall'Antonia ${ }^{1}$, Emerson Andrade Shiga ${ }^{1}$, Larissa Juliani Alvim ${ }^{1}$ and \\ Rosemeire Aparecida Bom Pessoni 1
}

Received: 29.06.2017; accepted: 9.01.2018

\begin{abstract}
Sugarcane bagasse as a source of carbon for enzyme production by filamentous fungi). The aim of the present work was to assess the enzymatic activity of six strains of filamentous fungi grown in liquid media containing $1 \%$ sugarcane bagasse as the sole carbon source. All fungal strains were able to use this agro-industrial residue, producing various types of enzymes, such as cellulases, xylanases, amylases, pectinases, and laccases. However, Aspergillus japonicus Saito was the most efficient producer, showing the highest enzymatic activity for laccase ( $395.73 \mathrm{U} \mathrm{L}^{-1}$ ), endo- $\beta-1,4-x y l a n a s e$ (3.55 $\left.\mathrm{U} \mathrm{mL}^{-1}\right)$ and $\beta$-xylosidase $\left(9.74 \mathrm{U} \mathrm{mL}^{-1}\right)$ at seven, fourteen and twenty-one days in culture, respectively. Furthermore, the endo- $\beta-1,4$-xylanases and $\beta$-xylosidases of $A$. japonicus showed maximum activity at $50^{\circ} \mathrm{C}$, and $\mathrm{pH} 5.5$ and $\mathrm{pH} 3.5-4.5$, respectively. Thus, these results indicate that $A$. japonicus has a great biotechnological potential for the production of these enzymes using sugarcane bagasse as the sole source of carbon.
\end{abstract}

Keywords: anamorphic fungi, Aspergillus japonicus, endo- $\beta$-1,4-xylanase, enzymes, laccase, $\beta$-xylosidase

RESUMO - (O bagaço de cana-de-açúcar como fonte de carbono para a produção de enzimas por fungos filamentosos). O presente trabalho teve como objetivo avaliar a atividade enzimática de seis cepas de fungos filamentosos cultivados em meio liquido contendo $1 \%$ de bagaço de cana-de-açúcar como a única fonte de carbono. Todas as cepas fúngicas foram capazes de usar este resíduo agroindustrial, produzindo vários tipos de enzimas, como celulases, xilanases, amilases, pectinases e lacases. No entanto, Aspergillus japonicus Saito foi o produtor mais eficiente, mostrando as maiores atividades enzimáticas para lacase $\left(395,73 \mathrm{U} \mathrm{L}^{-1}\right)$, endo- $\beta$-1,4-xilanase $\left(3,55 \mathrm{U} \mathrm{mL}^{-1}\right)$ e $\beta$-xilosidase $\left(9,74 \mathrm{U} \mathrm{mL}^{-1}\right)$ com sete, catorze, e vinte e um dias de cultura, respectivamente. Além disso, as endo- $\beta$-1,4-xilanases e as $\beta$-xilosidases de $A$. japonicus apresentaram atividade máxima a $50^{\circ} \mathrm{C}$, e pH 5,5 e pH 3,5-4,5, respectivamente. Assim, estes resultados indicam que $A$. japonicus tem um ótimo potencial biotecnológico para a produção destas enzimas utilizando o bagaço de cana-de-açúcar como a única fonte de carbono.

Palavras-chave: fungos anamórficos, Aspergillus japonicus, endo- $\beta$-1,4-xilanase, enzimas, lacase, $\beta$-xilosidase

\section{Introduction}

Sugarcane is the main agricultural crop cultivated in Brazil. The sugarcane stem is milled to obtain the cane juice, which is either used for ethanol or sugar production (Canilha et al. 2012). Each ton of sugarcane processed generates approximately $270-280 \mathrm{~kg}$ of bagasse (Rodrigues et al. 2003). This bagasse is normally burned in the industries to produce the energy required in the process (Canilha et al. 2012). However, this agro-industrial by-product may have more valuable uses than the direct energy generation through combustion (Gamez et al. 2006).
Sugarcane bagasse contains approximately $50 \%$ cellulose, $25 \%$ hemicellulose and $25 \%$ lignin. Due to its high availability, it could serve as a substrate for microbial production of value-added products, such as protein-rich animal feed, enzymes, amino acids, organic acids and compounds of pharmaceutical importance (Parameswaran 2009), and also source of carbon for the growth of filamentous fungi (Martins et al. 2011). Filamentous fungi are particularly useful producers of enzymes from the industrial point of view, due to the high production level and extra cellular secretion of enzymes, as well as relative ease

1. Universidade Metodista de São Paulo, Curso de Ciências Biológicas, Rua do Sacramento, 230, 09641-000, São Bernardo do Campo, SP, Brasil

2. Corresponding author: rosemeire.pessoni@metodista.br 
of cultivation (Tallapragada \& Venkatesh 2011). These fungi produce high levels of polysaccharide-degrading enzymes and are frequently used in the production of industrial enzymes (Tsukagoshi et al. 2001), such as amylases, cellulases, xylanases, pectinases, and ligninmodifying enzymes from lignocellulosic biomass. These enzymes have several biotechnological applications, for instance, they have been used in the production of textiles, detergents, paper, food for animals and humans for decades (Bocchini et al. 2003, Graminha et al. 2008). They can also be applied in industrial processes to eliminate the use of high temperatures, organic solvents, and extreme $\mathrm{pH}$, while at the same time offering increased reaction specificity, product purity and reduced environmental impact (Cherry \& Fidantsef 2003).

In the last few years, research has also been focused on the potential use of these fungal enzymes for the degradation of lignocellulosic materials, aiming at releasing fermentable sugars that can be converted to second-generation ethanol by the action of fermentative microorganisms (Buaban et al. 2010, Talebnia et al. 2010). The breakdown of lignocellulose in the plant cell wall requires the recruitment of glycoside hydrolases with different mechanisms of action in a concerted action with ligninases (Gupta et al. 2016). Moreover, pre-treatment using microbial enzymes for ethanol production is a promising technology due to its several advantages, like being an eco-friendly and economically viable strategy for enhancing enzymatic saccharification rates (Sindhu et al. 2015).

Lastly, there has been increasing interest in obtaining new, stable and more specific enzymes using low-cost carbon sources, such as the sugarcane bagasse, and in searching for new and suitable microbial strains for large-scale cultivation that might be able to enzymes with the appropriate characteristics for biotechnological processes (Parameswaran 2009). Therefore, the isolation of new fungal strains is the first step for obtaining more efficient and economically accessible enzymes for biotechnological and industrial purposes. Thus, the aim of this study was to assess the enzymatic activity of some strains of filamentous fungi, using sugarcane bagasse as the sole source of carbon.

\section{Materials and methods}

Strains and culture conditions - Strains of Aspergillus japonicus Saito, Fusarium solani (Mart.) Sacc.,
Fusarium sp. Link ex Fr., Fusarium oxysporum Schltdt., Pestalotiopsis sp. Steyaert, and Trichoderma pseudokoningii Rifai were obtained from the culture collection of the Laboratory of Microbiology of Universidade Metodista de São Paulo, São Bernardo do Campo, Brazil. Isolates were maintained in the laboratory on solid potato dextrose agar (PDA) slants at $25{ }^{\circ} \mathrm{C}$. Three discs ( $5 \mathrm{~mm}$ diameter) obtained from the cultures were transferred into $250 \mathrm{~mL}$ Erlenmeyer flasks containing $50 \mathrm{~mL}$ of the following medium (g L-1): (6) $\mathrm{NaNO}_{3},(1.5) \mathrm{KH}_{2} \mathrm{PO}_{4},(0.5) \mathrm{KCl},(0.5)$ $\mathrm{MgSO}_{4} .7 \mathrm{H}_{2} \mathrm{O}$, (0.01) $\mathrm{FeSO}_{4}$, (0.01) $\mathrm{ZnSO}_{4}$, and $1 \%$ sugarcane bagasse. The sugarcane bagasse was dried in an oven at $35{ }^{\circ} \mathrm{C}$ until constant weight and then crushed into particles of an average diameter of $4 \mathrm{~mm}$ (Alexandrino et al.2007), before adding to the liquid medium (Alexandrino et al. 2007). Flasks were kept at $25^{\circ} \mathrm{C}$ for 21 days under static conditions (Menezes et al. 2009). Culture growth was interrupted by filtration every 7 days and the crude culture filtrates used for enzymatic assays. All experiments were performed in triplicate.

Protein determination - Protein concentrations in the culture filtrate were estimated by the Bradford method using bovine serum albumin as standard (Bradford 1976). Triplicates of samples were analyzed in a spectrophotometer at $595 \mathrm{~nm}$.

Enzymatic assays - For all assays, one unit of enzymatic activity (U) was defined as the amount of enzyme that releases $1 \mu \mathrm{moL}$ of the corresponding product (glucose, xylose, galacturonic acid, $\rho$-nitrophenol, and oxidized syringaldazine), per minute under the assayed conditions.

Amylase, Endo- $\beta-1,4-x y l a n a s e$, Endo- $\beta-1,4-$ glucanase, Pectinase, and Filter paper activity (FPA) Activities - The amylase and endo- $\beta-1,4$-xylanase activities were determined by incubating $50 \mu \mathrm{L}$ of the crude culture filtrate, $50 \mu \mathrm{L}$ of starch, and birchwood xylan $1 \%(\mathrm{w} / \mathrm{v})$, respectively, in $50 \mathrm{mM}$ sodium citrate buffer ( $\mathrm{pH} 5.5)$ at $40{ }^{\circ} \mathrm{C}$ for 30 minutes. The endoglucanase and pectinase activities were determined by incubating $50 \mu \mathrm{L}$ of the crude culture filtrate, $50 \mu \mathrm{L}$ of carboxymethyl cellulose, and pectin $1 \%(\mathrm{w} / \mathrm{v})$, respectively, in $50 \mathrm{mM}$ sodium citrate buffer (pH 5.5) at $50{ }^{\circ} \mathrm{C}$ for 30 minutes. Filter paper activity (FPA) was determined by incubating $50 \mathrm{mg}$ of Whatman No.1 filter paper strips $(1.0 \times 6.0 \mathrm{~cm})$ in $500 \mu \mathrm{L}$ of the crude culture filtrate, and $500 \mu \mathrm{L}$ of sodium citrate buffer $50 \mathrm{mM}\left(\mathrm{pH} \mathrm{5.5)}\right.$ ) at $50{ }^{\circ} \mathrm{C}$ for 60 minutes (Ghose 1987). All reactions were stopped by 
adding $1 \mathrm{~mL}$ of 3,5-dinitrosalicylic acid (DNS) and then boiled for $10 \mathrm{~min}$, according to Miller (1959). The reducing sugar released from the substrate was measured in a spectrophotometer at $540 \mathrm{~nm}$.

$\beta$-glucosidase and $\beta$-xylosidase activities - The activity of $\beta$-glucosidases and $\beta$-xylosidases was determined by incubating $125 \mu \mathrm{L}$ of $\rho$-nitrophenyl$\beta$-D-glucopyranoside and $2 \mathrm{mM} \rho$-nitrophenyl- $\beta$-Dxylopyranoside, respectively, $125 \mu \mathrm{L}$ of the crude culture filtrate, and $250 \mu \mathrm{L}$ of $50 \mathrm{mM}$ sodium citrate buffer ( $\mathrm{pH} 5.5$ ) at $40^{\circ} \mathrm{C}$ for 30 minutes. Reactions were stopped by adding $500 \mu 1$ of $0.5 \mathrm{M} \mathrm{Na}_{2} \mathrm{CO}_{3}$ (Mayrink 2010). The p-nitrophenolate ion released from the substrate was measured in a spectrophotometer at $405 \mathrm{~nm}$.

Laccase Activity - The laccase activity was determined by incubating $0.2 \mathrm{~mL}$ of syringaldazine in $0.5 \mathrm{mM}$ ethanol, $0.1 \mathrm{~mL}$ of the crude culture filtrate, and 1.5 $\mathrm{mL}$ of $100 \mathrm{mM}$ phosphate buffer $(\mathrm{pH} 6.5)$ at $30{ }^{\circ} \mathrm{C}$ for 30 minutes (Leonowicz \& Grzywnowicz 1981). Oxidation of syringaldazine was measured in a spectrophotometer at $525 \mathrm{~nm}$. One unit of laccase activity was defined as $1 \mu \mathrm{mol}$ of syringaldazine oxidized per min.

Enzymatic characterization - Samples of a 7-day crude culture filtrate from A. japonicus were used to assess the effect of $\mathrm{pH}$ and temperature on the endo- $\beta-1,4-$ xylanase and $\beta$-xylosidase activities. For determining the optimum temperature of these enzymes, samples were incubated for $30 \mathrm{~min}$ in a range of temperatures from $20^{\circ} \mathrm{C}$ to $60^{\circ} \mathrm{C}$, and a $\mathrm{pH}$ of 5.5 held with sodium citrate buffer. The optimum $\mathrm{pH}$ of these enzymes was determined by incubating the samples at $50{ }^{\circ} \mathrm{C}$ and in a $\mathrm{pH}$ range of 2 to 7 with citrate-phosphate buffer, for 30 minutes. The enzymatic activities were performed as previously described, and the values were expressed as relative percentages.

Data Analysis - Data were analyzed by a one-way ANOVA (Sodek ${ }^{\circledR}$ Scopus Tecnologia S.A, version 3.02), comparing the enzymatic activities between days of culture of the same strain and between different strains, and then the average of three replicates was examined with Tukey's test $(\mathrm{p} \leq 0.05)$.

\section{Results}

Enzymatic Activities - Table 1 shows the cellulase activity of the six filamentous fungi grown in liquid medium with sugarcane bagasse as the sole carbon source. Most fungi showed a maximum FPA between 14 and 21 days. The highest FPA activities were produced by $A$. japonicus $\left(0.14 \mathrm{U} \mathrm{mL}^{-1}\right)$ and F. oxysporum $\left(0.13 \mathrm{U} \mathrm{mL}^{-1}\right)$ at days 14 and 21 , respectively, whereas the lowest FPA was exhibited by Fusarium sp. and F. solani. The strains of $F$. oxysporum, T. pseudokoningii, and Pestalotiopsis sp. showed a gradual increase in the enzyme activity over time, while A. japonicus, F. solani and Fusarium sp. showed the least variation in their enzymatic activities. In addition, most fungi reached their maximum endo$\beta$-1,4-glucanase activity at 21 days of culture, but the highest activity of this enzyme $\left(0.10 \mathrm{U} \mathrm{mL}^{-1}\right)$ was exhibited by Aspergillus japonicus at 7 days of culture. Pestalotiopsis sp. and all Fusarium strains showed no endo- $\beta$-1,4-glucanase activity during some/all days of culture. On the other hand, the only strains that showed $\beta$-glucosidase activity were $F$. oxysporum

Table 1. $\beta$-glucosidase, endoglucanase, and FPA activities of fungal isolates grown in submerged cultures of sugarcane bagasse as the sole carbon source for seven, fourteen, and twenty-one days.

\begin{tabular}{lccccccccc}
\hline \multirow{2}{*}{ Fungal Species } & \multicolumn{3}{c}{$\beta$-glucosidase $\left(\mathrm{U} \mathrm{mL}^{-1}\right)$} & \multicolumn{2}{c}{ Endoglucanase $\left(\mathrm{U} \mathrm{mL}^{-1}\right)$} & \multicolumn{2}{c}{$\mathrm{FPA}\left(\mathrm{U} \mathrm{mL}^{-1}\right)$} \\
\cline { 2 - 9 } & 7 days & 14 days & 21 days & 7 days & 14 days & 21 days & 7 days & 14 days & 21 days \\
\hline Aspergillus japonicus & $0.20 \mathrm{Aa}^{*}$ & $0.21 \mathrm{Aa}$ & $0.28 \mathrm{Aa}$ & $0.10 \mathrm{Aa}$ & $0.06 \mathrm{Ab}$ & $0.06 \mathrm{Ab}$ & $0.12 \mathrm{Aa}$ & $0.14 \mathrm{Aa}$ & $0.13 \mathrm{ABa}$ \\
Fusarium sp. & $0.00 \mathrm{Ba}$ & $0.00 \mathrm{Ba}$ & $0.00 \mathrm{Ba}$ & $0.00 \mathrm{Cb}$ & $0.00 \mathrm{Cb}$ & $0.02 \mathrm{CDa}$ & $0.04 \mathrm{Db}$ & $0.04 \mathrm{Db}$ & $0.05 \mathrm{DEa}$ \\
Fusarium solani & $0.00 \mathrm{Ba}$ & $0.00 \mathrm{Ba}$ & $0.00 \mathrm{Ba}$ & $0.00 \mathrm{Ca}$ & $0.00 \mathrm{Ca}$ & $0.00 \mathrm{Da}$ & $0.03 \mathrm{Da}$ & $0.04 \mathrm{Da}$ & $0.04 \mathrm{Ea}$ \\
$\begin{array}{l}\text { Fusarium } \text { oxysporum } \\
\text { Pestalotiopsis sp. }\end{array}$ & $0.00 \mathrm{Bb}$ & $0.06 \mathrm{Bab}$ & $0.19 \mathrm{Aa}$ & $0.00 \mathrm{Cc}$ & $0.02 \mathrm{Bb}$ & $0.04 \mathrm{ABCa}$ & $0.07 \mathrm{BCb}$ & $0.11 \mathrm{ABa}$ & $0.13 \mathrm{ABa}$ \\
$\begin{array}{l}\text { Trichoderma } \\
\text { pseudokoningii }\end{array}$ & $0.00 \mathrm{Ba}$ & $0.00 \mathrm{Ba}$ & $0.00 \mathrm{Ba}$ & $0.00 \mathrm{Cc}$ & $0.02 \mathrm{Bb}$ & $0.04 \mathrm{ABCa}$ & $0.05 \mathrm{CDa}$ & $0.07 \mathrm{Cb}$ & $0.09 \mathrm{BCc}$ \\
& $0.00 \mathrm{Ba}$ & $0.00 \mathrm{Ba}$ & $0.00 \mathrm{Ba}$ & $0.04 \mathrm{Bab}$ & $0.03 \mathrm{Bb}$ & $0.05 \mathrm{ABa}$ & $0.05 \mathrm{Db}$ & $0.07 \mathrm{Ca}$ & $0.08 \mathrm{CDa}$ \\
\hline
\end{tabular}

*Means followed by the same letters, lowercase in rows and capital letters in columns, showed no differences of statistical significance by Tukey's test $(\mathrm{p}<0.05)$. 
and $A$. japonicus, and their maximum activities were achieved at 21 days of culture. These two fungi also showed a higher activity of $\beta$-glucosidase than of endoglucanases and FPA.

The ability to produce amylase, pectinase, and laccase of the fungi in the culture medium is shown in table 2. Aspergillus japonicus was the only strain that produced amylase, with a maximum activity at 14 days of culture $\left(0.35 \mathrm{U} \mathrm{mL}^{-1}\right)$ (data not shown). Notwithstanding, all strains showed the maximum pectinase activity at 7 days of culture, and thereafter this activity decreased. The highest pectinase activity was observed in A. japonicus $\left(0.53 \mathrm{U} \mathrm{mL}^{-1}\right)$, while the other species tested showed low activity. Nonetheless, an optimum laccase activity was registered for almost all strains at 14 days of culture. The highest activity of this enzyme was observed for A. japonicus (395.73 $\mathrm{U} \mathrm{L}^{-1}$ ) at 7 days, but it decreased at 14 and 21 days of culture.

The endo- $\beta$-1,4-xylanase and $\beta$-xylosidase activities of the strains in the liquid medium is shown in table 3 . The highest endo- $\beta-1,4$-xylanase (3.55 $\left.\mathrm{U} \mathrm{mL}^{-1}\right)$ and $\beta$-xylosidase $\left(9.74 \mathrm{U} \mathrm{mL}^{-1}\right)$ activities were observed for A. japonicus at 14 and 21 days of culture, respectively. The rest of the strains showed low enzymatic activities of both enzymes. The strain of $A$. japonicus presented a higher production of $\beta$-xylosidases than of endo- $\beta$-1,4-xylanases at all days of culture, while the other species presented higher activities of endo- $\beta-1,4$-xylanase than of $\beta$-xylosidase. We also registered lower cellulase activities than of these two enzymatic activities.

Enzymatic characterization - In A. japonicus, the endo$\beta$-1,4-xylanases and $\beta$-xylosidase were the enzymes with the highest activity, and both tended to increase over time (table 3 ). Based on these results, we only evaluated the specific activity of endo- $\beta-1,4$-xylanase and $\beta$-xylosidase (table 4 ). The specific activity of endo- $\beta$-1,4-xylanase and $\beta$-xylosidase was consistent with the pattern of enzymatic activity exhibited, as shown in table 3.

Effects of temperature and $\mathrm{pH}$ - Both endo- $\beta-1,4-$ xylanases and $\beta$-xylosidases showed their maximum activity at $50{ }^{\circ} \mathrm{C}$, and at $\mathrm{pH} 5.5$ and 3.5 to 4.5 , respectively (figure $1 \mathrm{a}$ and $\mathrm{b}$ ).

\section{Discussion}

The FPA activities of Aspergillus japonicus and F. oxysporum are shown in table 1 . Our results are in agreement with previous studies, which showed an activity of $0.16 \mathrm{FPA} \mathrm{mL}^{-1}$ for Trichoderma reesei QM9414 grown in sugarcane bagasse (Basso et al. 2010), and of $0.159 \mathrm{FPA} \mathrm{mL}^{-1}$ for $A$. terreus in banana stems (Siqueira et al. 2010). However, Mayrink (2010) found a higher FPA for A. japonicus (3.26 FPA mL-1), when grown in wheat bran. Previous studies also indicated that $A$. japonicus has the potential for cellulase production (Herculano et al. 2011, Kumar et al. 2008).

The endoglucanase activity has been previously reported for several fungi grown in different agroindustrial residues. For example, Stroparo et al. (2012) reported endoglucanase activity in Penicillium miczninscii grown in pineapple peel $\left(0.18 \mathrm{U} \mathrm{mL}^{-1}\right)$ and orange peel $\left(0.15 \mathrm{U} \mathrm{mL}^{-1}\right)$. These findings are consistent with the endoglucanase activity of $A$. japonicus found in this work (table 1). In contrast, Gomes et al. (2007) found a higher endoglucanase activity (0.49

Table 2. Pectinase and laccase activities of fungal isolates grown in submerged cultures of sugarcane bagasse as the sole carbon source for seven, fourteen, and twenty-one days.

\begin{tabular}{lcccccc}
\hline \multirow{2}{*}{ Fungal Species } & \multicolumn{3}{c}{ Pectinase $\left(\mathrm{U} \mathrm{mL}^{-1}\right)$} & \multicolumn{3}{c}{ Laccase $\left(\mathrm{U} \mathrm{L}^{-1}\right)$} \\
\cline { 2 - 7 } & 7 days & 14 days & 21 days & 7 days & 14 days & 21 days \\
\hline Aspergillus japonicus & $0.53 \mathrm{Aa}^{*}$ & $0.24 \mathrm{Ab}$ & $0.28 \mathrm{Ab}$ & $395.73 \mathrm{Aa}$ & $165.81 \mathrm{ABb}$ & $100.00 \mathrm{Cb}$ \\
Fusarium sp. & $0.10 \mathrm{BCa}$ & $0.08 \mathrm{Ba}$ & $0.09 \mathrm{Ba}$ & $82.91 \mathrm{CDc}$ & $131.28 \mathrm{ABb}$ & $209.40 \mathrm{Aa}$ \\
Fusarium solani & $0.19 \mathrm{Ba}$ & $0.09 \mathrm{Bb}$ & $0.11 \mathrm{Bb}$ & $194.87 \mathrm{BCa}$ & $217.09 \mathrm{Aa}$ & $205.13 \mathrm{ABa}$ \\
Fusarium oxysporum & $0.19 \mathrm{Ba}$ & $0.09 \mathrm{Bb}$ & $0.12 \mathrm{Bb}$ & $126.15 \mathrm{CDb}$ & $258.12 \mathrm{ABa}$ & $229.91 \mathrm{Ba}$ \\
Pestalotiopsis sp. & $0.00 \mathrm{Ca}$ & $0.00 \mathrm{Ca}$ & $0.00 \mathrm{Ca}$ & $28.72 \mathrm{Db}$ & $126.50 \mathrm{Ba}$ & $111.11 \mathrm{Ca}$ \\
Trichoderma pseudokoningii & $0.08 \mathrm{Ba}$ & $0.02 \mathrm{Cb}$ & $0.03 \mathrm{Cb}$ & $182.05 \mathrm{BCb}$ & $227.35 \mathrm{ABab}$ & $257.26 \mathrm{ABa}$ \\
\hline
\end{tabular}

*Means followed by the same letters, lowercase in rows and capital letters in columns, showed no differences of statistical significance by Tukey's test $(\mathrm{p}<0.05)$. 
Table 3. Endo- $\beta-1,4$-xylanase and $\beta$-xylosidase of fungal isolates grown in submerged culture of sugarcane bagasse as the sole carbon source for seven, fourteen, and twenty-one days.

\begin{tabular}{lcccccc}
\hline \multirow{2}{*}{ Fungal Species } & \multicolumn{2}{c}{ Endo- $\beta-1,4$-xylanase $\left(\mathrm{U} \mathrm{mL}^{-1}\right)$} & \multicolumn{3}{c}{$\beta$-xylosidase $\left(\mathrm{U} \mathrm{mL}^{-1}\right)$} \\
\cline { 2 - 7 } & 7 days & 14 days & 21 days & 7 days & 14 days & 21 days \\
\hline Aspergillus japonicus & $2.47 \mathrm{Ab} *$ & $3.55 \mathrm{Aa}$ & $2.94 \mathrm{Ab}$ & $4.48 \mathrm{Ab}$ & $8.31 \mathrm{Aa}$ & $9.74 \mathrm{Aa}$ \\
Fusarium sp. & $0.13 \mathrm{Cb}$ & $0.13 \mathrm{Db}$ & $0.30 \mathrm{Ba}$ & $0.00 \mathrm{Ba}$ & $0.00 \mathrm{Ba}$ & $0.00 \mathrm{Ba}$ \\
Fusarium solani & $0.20 \mathrm{BCc}$ & $0.45 \mathrm{BCb}$ & $0.50 \mathrm{Ba}$ & $0.53 \mathrm{Ba}$ & $0.32 \mathrm{Bab}$ & $0.32 \mathrm{Bb}$ \\
Fusarium oxysporum & $0.45 \mathrm{Bb}$ & $0.56 \mathrm{Bab}$ & $0.63 \mathrm{Ba}$ & $0.04 \mathrm{Bb}$ & $0.24 \mathrm{Ba}$ & $0.25 \mathrm{Ba}$ \\
Pestalotiopsis sp. & $0.07 \mathrm{Cc}$ & $0.26 \mathrm{CDb}$ & $0.45 \mathrm{Ba}$ & $0.06 \mathrm{Bb}$ & $0.15 \mathrm{Ba}$ & $0.00 \mathrm{Bc}$ \\
Trichoderma & $0.07 \mathrm{Cc}$ & $0.26 \mathrm{CDb}$ & $0.47 \mathrm{Ba}$ & $0.00 \mathrm{Ba}$ & $0.00 \mathrm{Ba}$ & $0.00 \mathrm{Ba}$ \\
pseudokoningii & & & & & &
\end{tabular}

*Means followed by the same letters, lowercase in rows and capital letters in columns, showed no differences of statistical significance by Tukey's test $(\mathrm{p}<0.05)$.

Table 4. Specific activity $\left(\mathrm{U} \mathrm{mg}^{-1}\right)$ of endo- $\beta-1,4$-xylanase and $\beta$-xylosidase obtained from crude culture filtrates of Aspergillus japonicus grown in sugarcane bagasse for seven, fourteen, and twenty-one days.

\begin{tabular}{cccc}
\hline \multirow{2}{*}{ Enzymes } & \multicolumn{3}{c}{ Specific Activity $\left(\mathrm{U} \mathrm{mg}^{-1}\right)$} \\
\cline { 2 - 4 } & 7 days & 14 days & 21 days \\
\hline Endo- $\beta$-1,4-xylanase & $173.81 \pm 8.72$ & $172.06 \pm 24.30$ & $163.40 \pm 12.84$ \\
$\beta$-xylosidase & $315.39 \pm 48.26$ & $402.30 \pm 77.80$ & $540.82 \pm 95.28$ \\
\hline
\end{tabular}
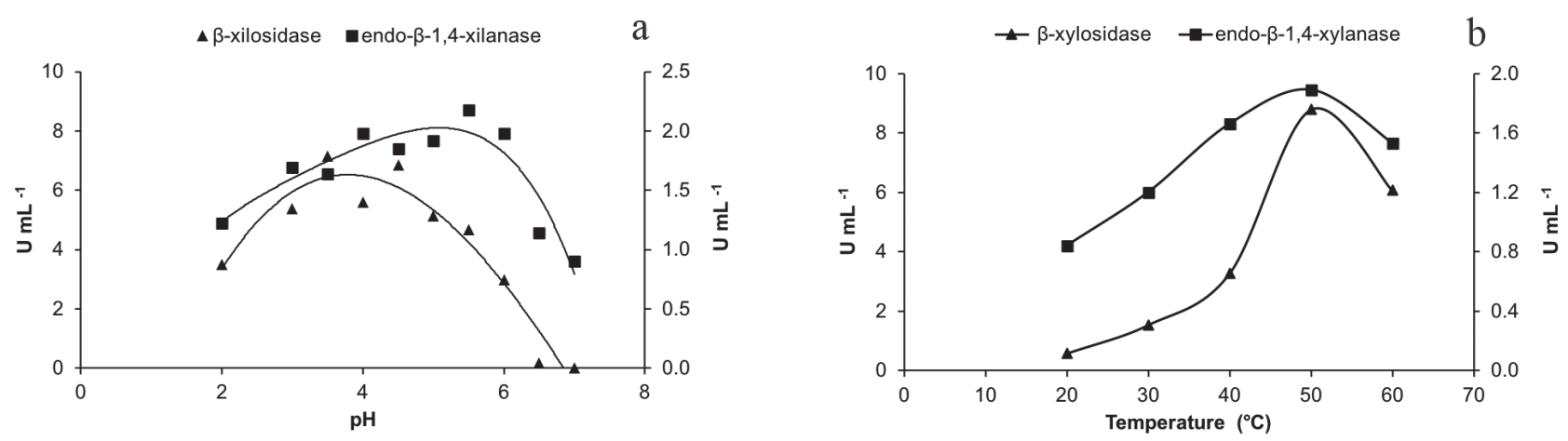

Figure 1. Effect of temperature (a) and $\mathrm{pH}$ (b) on the endo- $\beta-1,4$-xylanase and $\beta$-xylosidase activities of Aspergillus japonicus grown in sugarcane bagasse as the sole carbon source for seven days. The values are means of three experiments $(n=3)$.

$\left.\mathrm{U} \mathrm{mL}^{-1}\right)$ in Trichoderma viride grown in sugarcane bagasse, while Siqueira et al. (2010) in Aspergillus oryzae $\left(0.223 \mathrm{U} \mathrm{mL}^{-1}\right)$ and $A$. terreus $\left(0.519 \mathrm{U} \mathrm{mL}^{-}\right.$ $\left.{ }^{1}\right)$ grown in cotton and banana stems, respectively. Singh et al. (2009) and Castro et al. (2010) found that Aspergillus species are the best producers of exo and endoglucanases, and that the concentrations of $\beta$-glucosidases produced by species of this genus are particularly high, which may represent an advantage in the process of biomass saccharification.

Only A. japonicus and F. oxysporum exhibited $\beta$-glucosidase activity (table 1 ), which was lower than reported in previous studies. Some authors have reported higher $\beta$-glucosidase activities for $A$. niger (3 $\mathrm{U} \mathrm{mL}^{-1}$ ) and for A. japonicus $\left(1.79 \mathrm{U} \mathrm{mL}^{-1}\right)$ both grown in wheat bran (Bansal et al. 2011, Mayrink 2010), and for F. proliferatum (3.31 $\mathrm{U} \mathrm{mL}^{-1}$ ) grown in corn stover (Gao et al. 2012). Among the fungi analyzed, A. japonicus and $F$. oxysporum seem to be the most efficient cellulose degraders. Bansal et al. (2011) observed that Aspergillus usually present a high $\beta$-glucosidase activity but low endoglucanase levels, whereas Trichoderma has high endoglucanase and exoglucanase activities but low $\beta$-glucosidase levels, 
and hence, this latter fungus has a limited efficiency in cellulose hydrolysis. The same pattern was registered in this study, indicating a greater saccharification of cellulose by $A$. japonicus. The characteristics of the $\beta$-glucosidase produced by $A$. japonicus have been previously assessed for a potential use in biomass saccharification (Korotkova et al. 2009).

Pasin et al. (2014) reported high levels of amylase activity in A. japonicus when cultivated in different agro-industrial residues. The presence of this activity in the cultures might be due to the fact that amylases are constitutive enzymes, which are generally located in the fungal cell walls (Benassi et al. 2012).

Our results of pectinase activity from $A$. japonicus are in agreement with Teixeira (2000), who reported a pectinase activity of $0.50 \mathrm{U} \mathrm{mL}^{-1}$ for $A$. japonicus 586 , in the presence of $0.5 \%$ pectin and $0.5 \%$ glucose (table 2). However, higher fungal pectinase activities have been reported in the literature; for instance, Penicillium verruculosum reached $10.32 \mathrm{U} \mathrm{mL}^{-1}$ in culture media supplemented with orange peel (Stroparo et al. 2012), and Aspergillus niger LB02-SF exhibited $14 \mathrm{U} \mathrm{mL}^{-1}$, when pectin was added to the medium (Reginatto et al. 2017). Despite this, several pectinases have been hitherto reported for $A$. japonicus, such as endopolygalacturonases and pectinesterases (Hasunuma et al. 2003, Semenova et al. 2003, Teixeira et al. 2011), pectin lyases (Semenova et al. 2003, Ishii \& Yokotsuka 1975), and exo-polygalacturonases (Teixeira et al. 2011), indicating that this species can be highly promising for the production of these enzymes.

Interestingly, the studied strains showed a higher laccase activity than reported by Okamoto et al. (2000) and Mansur et al. (2003), who found a laccase activity of $130 \mathrm{U} \mathrm{L}^{-1}$ and $310 \mathrm{U} \mathrm{L}^{-1}$, respectively for P. ostreatus (table 2). According to Kiiskinen et al. (2004), the majority of the laccases characterized so far have been found in white-rot fungi, which are efficient lignin degraders. Unlike results from previous studies, we observed that the fungi analyzed in the present study might have the potential to produce this enzyme, especially in the case of $A$. japonicus, which showed the highest laccase activity, and has been previously reported as an efficient degrader of phenolic compounds using wheat straw as source of carbon (Milstein et al. 1983).

It is important to note that in A. japonicus we found higher activities of endo- $\beta-1,4-x y l a n a s e$ and $\beta$-xylosidase than of other enzymes, except in the case of laccase (table 3). Siqueira et al. (2010) found similar activities of endo- $\beta-1,4$-xylanases produced by various strains of Aspergillus grown in banana stems, cotton residues, and sugarcane bagasse. Other studies have also found a high endo- $\beta-1,4$-xylanase activity from fungi grown in sugarcane bagasse; for example, Lemos et al. (2000) in A. awamori $\left(30 \mathrm{U} \mathrm{mL}^{-1}\right)$, Biswas et al. (1988) in A. ochraceus $\left(8.5 \mathrm{U} \mathrm{mL}^{-1}\right)$, and Kadowaki et al. (1997) in A. tamarii $\left(16.7 \mathrm{U} \mathrm{mL}^{-1}\right)$. We also noted that the activity of $\beta$-xylosidase produced by $A$. japonicus in sugarcane bagasse was higher than reported in previous studies. Biswas et al. (1988) and Smith \& Wood (1991) have reported the production of $\beta$-xylosidases by $A$. ochraceus $\left(5.70 \mathrm{U} \mathrm{mL}^{-1}\right)$ and A. awamori $\left(2.86 \mathrm{U} \mathrm{mL}^{-1}\right)$ when grown in submerged cultures of milled oat straw.

Aspergillus japonicus showed a higher activity of $\beta$-xylosidase than of endo- $\beta$-1,4-xylanase when grown in sugarcane bagasse (table 3 ). This can be due to the fact that $\beta$-xylosidases are responsible for removing xylooligosaccharides, which are inhibitors of xylanases, and thus allowed a more efficient hydrolysis of xylan. According to Polizeli et al. (2005) the ideal microorganism for biotechnological purposes would be the one that produces an adequate amount of each of the enzymes of the xylanolytic complex. In this sense, A.japonicus appears to be an efficient producer of $\beta$-xylosidase and endo- $\beta-1,4$-xylanase, and this might be a strategy of this fungus for breaking down hemicelluloses from sugarcane bagasse in order to use them for rapid growth. In addition, we found a lower activity of cellulases than of endo- $\beta-1,4$-xylanases and $\beta$-xylosidases (table 1 and 3 ). This may be related to different factors that prevent the hydrolysis of cellulose, such as, cellulose crystallinity, accessible surface area, protection by lignin, and sheathing by hemicellulose (Kumar et al. 2009).

Regarding the specific activity of endo- $\beta-1,4-$ xylanase and $\beta$-xylosidase, we found that $A$. japonicus showed a high specific activity for both enzymes when grown in sugarcane bagasse (table 4) and that these activities were higher than reported in previous studies. For example, Guimaraes et al. (2013) reported that the specific activity of xylanase for Aspergillus niger and A. flavus in different sources of carbon did not exceed $20 \mathrm{U} \mathrm{mg}^{-1}$, while Rizzatti et al. (2001) reported a $\beta$-xylosidase activity for $A$. phoenicis of $219.9 \mathrm{U} \mathrm{mg}^{-1}$ grown in sugarcane bagasse and of $112.3 \mathrm{U} \mathrm{mg}^{-1}$ in maize pith as sole carbon sources.

Remarkably, we found that $A$. japonicus, when grown in sugarcane bagasse, has a lower temperature for endo- $\beta$ 1,4-xylanase and $\beta$-xylosidase activities (figure $1 \mathrm{a}$ and $\mathrm{b}$ ) 
than reported by Wakiyama et al. (2008) and Semenova et al. (2009), although the $\mathrm{pH}$ range for these enzymes was similar. These authors did not use any agroindustrial residue as source of carbon and found optimal endo- $\beta-1,4-$ xylanase and $\beta$-xylosidase activities for the same strain at $60^{\circ} \mathrm{C}-70{ }^{\circ} \mathrm{C}$ and $\mathrm{pH}$ 4.0-5.0. Polizeli et al. 2005 also reported maximum activity of both endoxylanase and $\beta$-xylosidase between $40{ }^{\circ} \mathrm{C}$ and $80^{\circ} \mathrm{C}$, and $\mathrm{pH} 4.0$ and 6.5. Some species of Aspergillus have shown an optimum temperature for endo- $\beta$-1,4-xylanase activity of $50^{\circ} \mathrm{C}$ (Polizeli et al.2005), as in the case of A. fumigatus at $55^{\circ} \mathrm{C}$ and pH 5.5 (Silva et al. 1999). In the case of $\beta$-xylosidase, the optimum temperature and $\mathrm{pH}$ range for $A$. phoenicis were at $75^{\circ} \mathrm{C}$ and pH 4.0-4.5 (Rizzatti et al. 2001), and for A. cf. tubingensis LAMAI 31 at $55^{\circ} \mathrm{C}$ and pH 5.0 (Santos et al. 2016).

\section{Conclusion}

Our results showed that Aspergillus japonicus, when cultivated in sugarcane bagasse as the sole source of carbon, presented the most promising results for enzymatic activities. This fungus showed the highest activities of laccase, endo- $\beta-1,4$-xylanase, and $\beta$-xylosidase at 7,14 and 21 days of culture, respectively. This strain was also able to produce the maximum activity of endo- $\beta$-1,4-xylanases and $\beta$-xylosidases at low temperature when compared to other studies. Therefore, A. japonicus appears to be an effective enzymatic producer when grown in sugarcane bagasse, suggesting its potential application in biotechnological processes that require the production of these enzymes.

\section{Acknowledgments}

The authors acknowledge the financial support from $\mathrm{CNPq}$ (National Council for Scientific and Technological Development) No. 11725720125 and the scholarship from Capes (Coordination for the Improvement of Higher Education Personnel) - Proc. No. 88888.094429/2013-00. The authors thank Dr. John J. Kelly and Sean Kemper, Loyola University of Chicago, for their critical revision and helpful comments on the manuscript. We also thank Dr. Agostina Virginia Marano for the English revision.

\section{Literature cited}

Alexandrino, A.M., Faria, H.G., Souza, C.G.M. \& Peralta, R.M. 2007. Reutilisation of Orange Waste for Production of Lignocellulolytic Enzymes by Pleurotus ostreatus (Jack:Fr). Ciência e Tecnologia de Alimentos 27: 364-368.
Bansal, N., Tewari, R., Gupta, J.K., Soni, R. \& Soni, S. K. 2011. A novel strain of Aspergillus niger producing a cocktail of hydrolytic depolymerising enzymes for the production of second generation biofuels. BioRes 6: 552-569.

Basso, T.P., Gallo, C.R. \& Basso, L.C. 2010. Cellulolytic activity of isolated fungi from sugarcane bagasse and decayed wood. Pesquisa Agropecuária Brasileira 45: $1282-1289$.

Benassi, V.M., Lucas, R.C., Michelin, M., Jorge, J.A, Terenzi, H.F. \& Polizeli, M.L.T.M. 2012. Production and action of an Aspergillus phoenicis enzymatic pool using different carbon sources. Brazilian Journal of Food Technology 15: 253-260.

Biswas, S.R., Mishra, A.K. \& Nanda, G. 1988. Xylanase and $\beta$-xylosidase production by Aspergillus ochraceus during growth on lignocelluloses. Biotechnology and Bioengineering 31: 613-616.

Bocchini, D.A., Damiano, V.B., Gomes, E. \& Silva, R. 2003. Effect of Bacillus circulans D1 Thermostable Xylanase on Biobleaching of Eucalyptus Kraft Pulp. Applied Biochemistry and Biotechnology 105: 393-401.

Bradford, M.M. 1976. A rapid and sensitive method for the quantitation of microgram quantities of protein utilizing the principle of protein-dye binding. Analytical Biochemistry 72: 248-254.

Buaban, B., Inoue, H., Yano, S., Tanapongpipat, S., Ruanglek, V., Champreda, V., Pichyangkura, R., Rengpipat, S. \& Eurwilaichitr, L. 2010. Bioethanol Production from Ball Milled Bagasse Using an OnSite Produced Fungal Enzyme Cocktail and XyloseFermenting Pichia Stipitis. Journal of Bioscience and Bioengineering 110: 18-25.

Canilha, L., Chandel, A.K., Milessi, T.S.S., Antunes, F.A.F., Freitas, W.L.C., Felipe, M.G.A. \& Silva, S.S. 2012. Bioconversion of Sugarcane Biomass into Ethanol: An Overview about Composition, Pretreatment Methods, Detoxification of Hydrolysates, Enzymatic Saccharification, and Ethanol Fermentation. Journal of Biomedicine and Biotechnology 2012: 1-15.

Castro, A.M., Albuquerque de Carvalho, M.L., Leite, S.G.F. \& Pereira Jr., N. 2010. Cellulases from Penicillium funiculosum: production, properties and application to cellulose hydrolysis. Journal of Industrial Microbiology \& Biotechnology 37: 151-158.

Cherry, J.R. \& Fidantsef, A.L. 2003. Directed evolution of industrial enzymes: an update. Current Opinion in Biotechnology 14: 438-443.

Gamez, S., Gonzalez-Cabriales, J.J., Ramirez, J.A. \& Garrote, G. 2006. Study of the hydrolysis of sugar cane bagasse using phosphoric acid. Journal of Food Engineering 74: 78-88.

Gao, Z., Van Hop, D., Yen, L.T.H., Ando, K., Hiyamula, S. \& Kondo, R. 2012. The production of $\beta$-glucosidases by Fusarium proliferatum NBRC109045 isolated from Vietnamese forest. AMB Express 49: 1-13. 
Ghose, T.K. 1987. Measurement of Cellulase Activities. Pure and Applied Chemistry 59: 257-268.

Gomes, E., Guez, M.A.U., Martin, N. \& Silva, R. 2007. Thermostable Enzymes: Sources, Production and Industrial Applications. Química Nova 30: 136-145.

Graminha, E.B.N., Gonçalves, A.Z.L., Pirota, R.D.P.B., Balsalobre, M.A.A., Silva, R. \& Gomes, E. 2008. Enzyme Production by Solid-State Fermentation: Application to Animal Nutrition. Animal Feed Science and Technology 144: 1-22.

Guimaraes, N.C.A., Sorgatto, M., Peixoto-Nogueira, S.C., Betini, J.H.A., Zanoelo, F.F., Marques, M.R., Polizeli, M.L.T.M. \& Giannesi, G.C. Bioprocess and biotechnology: effect of xylanase from Aspergillus niger and Aspergillus flavus on pulp biobleaching and enzyme production using agroindustrial residues as substract. SpringerPlus 380: 1-7.

Gupta, V.K., Kubicek, C.P., Berrin, J.G., Wilson, D.W., Couturie, M., Berlin, A., Ferreira Filho, E.X. \& Ezeji, T. 2016. Fungal enzymes for bio-products from sustainable and waste biomass. Trends in Biochemical Sciences 41: 633-645.

Hasunuma, T., Fukusaki, E. \& Kobayashi, A. 2003. Methanol production is enhanced by expression of an Aspergillus niger pectin methylesterase in tobacco cells. Journal of Biotechnology 106: 45-52.

Herculano, P.N., Porto, T.S., Moreira, K.A., Pinto, G.A.S., Souza-Motta, C.M. \& Porto, A.L. 2011. Cellulase Production by Aspergillus japonicus URM5620 Using Waste from Castor Bean (Ricinus communis L.). Applied Biochemistry and Biotechnology 165: 1057-1067.

Ishii, S. \& Yokotsuka, T. 1975. Purification and Properties of Pectin Lyase from Aspergillus japonicus. Agricultural and Biological Chemistry 39: 313-321.

Kiiskinen, L.L., Kruus, K., Bailey, M., Ylösmäki, E., Siika-Aho, M. \& Saloheimo, M. 2004. Expression of Melanocarpus albomyces laccase in Trichoderma reesei and characterization of the purified enzyme. Microbiology 150:3065-3074.

Korotkova, O.G., Semenova, M.V., Morozova, V.V., Zorov, I.N., Sokolova, L.M., Bubnova, T.M., Okunev, O.N. \& Sinitsyn, A.P. 2009. Isolation and properties of fungal $\beta$-glucosidases. Biochemistry (Moscow) 74: 569-577.

Kumar, R., Singh, S. \& Singh, O.V. 2008. Bioconversion of lignocellulosic biomass: Biochemical and molecular perspectives. Journal of Industrial Microbiology \& Biotechnology 35: 377-391.

Kumar, P., Barret,t D.M., Delwiche, M.J. \& Stroeve, P. 2009. Methods for pretreatment of lignocellulosic biomass for efficient hydrolysis and biofuel production. Industrial \& Engineering Chemistry Research 48: 3713-3729.
Lemos, J.L.S., Bon, E.P.S., Santana, M.F.E., Pereira Jr., N. 2000. Thermal stability of xylanases produced by Aspergillus awamori. Brazilian Journal of Microbiology 31: 206-211.

Leonowicz, A. \& Grzywnowicz, K. 1981. Quantitative estimation of laccase forms in some white-rot fungi using syringaldazine as a substrate. Enzyme and Microbial Technology 3: 55-58.

Mansur, M., Arias, M.E., Copa-Patiño, J.L., Flärdh, M. \& González, A.E. 2003. The white-rot fungus Pleurotus ostreatus secretes laccase isozymes with different substrate specificities. Mycologia 95: 1013-1020.

Martins, D.A.B., Prado, H.F.A., Leite, R.S.R., Ferreira, H., Moretti, M.M.S., Silva, R. \& Gomes, E. 2011. Agroindustrial wastes as substrates for microbial enzymes production and source of sugar for bioethanol production. In: S. Kumar (ed.). Integrated Waste Management - Volume II, 319-360.

Mayrink, M.I.C.B. 2010. Produção de enzimas fúngicas e avaliação do potencial das celulases na sacarificação da celulose, Minas Gerais, Brazil. Dissertação de Mestrado, Universidade Federal de Viçosa.

Menezes, C.R., Silva, I.S. \& Durrant, L.R. 2009. Sugarcane bagasse: Source for the production of ligninocelullolytic enzymes. Estudos Tecnológicos em Engenharia 5: 68-78.

Miller, G.L. 1959. Use of dinitrosalicylic acid reagent for determination of reducing sugar. Analytical Chemistry 31: 426-428.

Milstein, O.A., Vered, Y., Sharma, A., Gressel, J. \& Flowers, H.M. 1983. Fungal Biodegradation and Biotransformation of Soluble Lignocarbohydrate Complexes from Straw. Applied and Environment Microbiology 46: 55-61.

Okamoto, K., Yanagi, S.O. \& Sakai, T. 2000. Purification and characterization of extracellular laccase from Pleurotus ostreatus. Mycoscience 41: 7-13.

Parameswaran, B. 2009. Sugarcane Bagasse. In: P.S.N. Nigam, P., A. Pandey (ed.). Biotechnology for agroindustrial residues utilisation - Utilisation of agroresidues. Springer, pp. 239-252.

Pasin, T.M., Benassi, V.M., Moreira, E.A., Jorge, J.A. \& Polizeli, M.L.T.M. 2014. Prospecting Filamentous Fungi for Amylase Production: Standardization of Aspergillus japonicus Culture Conditions. British Biotechnology Journal 4: 482-498.

Polizeli, M.L.T.M., Rizzatti, A.C.S., Monti, R., Terenzi, H.F., Jorge, J.A. \& Amorim, D.S. 2005. Xylanases from fungi: properties and industrial applications. Applied Microbiology Biotechnology 67: 577-591.

Reginatto, C., Rossi, C., Miglioranza, B.G., Santos, M., Meneghel, L., Silveira, M.M. \& Malvessi, E. 2017. Pectinase production by Aspergillus niger LB-02-SF is influenced by the culture medium composition and the addition of the enzyme inducer after biomass growth. Process Biochemistry 58: 1-8. 
Rizzatti, A.C., Jorge, J.A., Terenzi, H.F., Rechia, C.G. \& Polizeli, M.L. 2001. Purification and properties of a thermostable extracellular $\beta$-D-xylosidase produced by a thermotolerant Aspergillus phoenicis. Journal of Industrial Microbiology \& Biotechnology 26: 156-160.

Rodrigues, R.C.L.B., Felipe, M.D.G.A., Silva, J.B. A. \& Vitolo, M. 2003. Response surface methodology for xylitol production from sugarcane bagasse hemicellulosic hydrolyzate using controlled vacuum evaporation process variables. Process Biochemistry 38: 1231-1237.

Santos, J.A., Vieira, J.M.F., Videira, A., Meirelles, L.A., Rodrigues, A., Taniwaki, M.H. \& Sette, L.D. 2016. Marine-derived fungus Aspergillus cf. tubingensis LAMAI 31: a new genetic resource for xylanase production. AMB Express 25: 1-10.

Semenova, M.V., Drachevskaya, M.I., Sinitsyna, O.A., Gusakov, A.V. \& Sinitsyn, A.P. 2009. Isolation and properties of extracellular $\beta$-xylosidases from Fungi Aspergillus japonicus and Trichoderma reesei. Biochemistry (Moscow) 74: 1002-1008.

Semenova, M.V., Grishutin, S.G., Gusakov, A.V., Okunev, O.N. \& Sinitsyn, A.P. 2003. Isolation and properties of pectinases from the fungus Aspergillus japonicus. Biochemistry (Moscow) 68: 559-569.

Sindhu, R., Binod, P., Pandey, A. 2016. Biological pretreatment of lignocellulosic biomass - an overview. Bioresource Technology 199: 76-82.

Silva, C.H.C., Puls, J., Sousa, M.V. \& Ferreira Filho, E.X. 1999. Purification and characterization of a low molecular weight xylanase from solid-state cultures of Aspergillus fumigatus Fresenius. Brazilian Journal of Microbiology 30: 114-119.

Singh, R., Varma, A.J., Laxman, R.S. \& Rao, M. 2009. Hydrolysis of cellulose derived from steam exploded bagasse by Penicillium cellulases: comparison with commercial cellulose. Bioresource Technology 100: 6679-6681.

Siqueira, F.G., Siqueira, E.G., Jaramillo, P.M.D., Silveira, M.H.L., Andreaus, J., Couto, F.A., Batista, L.R. Ferreira Filho, E.X. 2010. The potential of agroindustrial residues for production of holocellulase from filamentous fungi. International Biodeterioration \& Biodegradation 64:20-26.
Smith, D.C. \& Wood, T.M. 1991. Xylanase production by Aspergillus awamori. Development of medium and optimization of the fermentation parameters for the production of extracellular xylanase and $\beta$-xylosidase while maintaining low protease production. Biotechnology and Bioengineering 38: 883-890.

Stroparo, E.C., Beitel, S.M., Resende, J.T.V. \& Knob, A. 2012. Filamentous fungi and agro-industrial residues selection for enzyme production of biotechnological interest. Semina: Ciências Agrárias 33: 2267-2278.

Tallapragada, P., Venkatesh, K. 2011. Isolation, identification and optimization of xylanase enzyme produced by Aspergillus niger under submerged fermentation. Journal of Microbiology and Biotechnology Research 1: 137-147.

Talebnia, F., Karakashev, D. \& Angelidaki, I. 2010. Production of Bioethanol from Wheat Straw: an Overview on Pretreatment, Hydrolysis and Fermentation. Bioresource Technology 101: 4744-4753.

Takahashi, J.P., Pelegrini, A., Pereira, C.Q.M. \& Souza, M.C. 2011. Incidence of keratinophilic fungi in soils of public parks and squares of São Bernardo do Campo City. Revista de Biologia e Ciências da Terra 11: 47-53.

Teixeira, M.F.S., Andrade, J.S., Fernandes, O.C.C., Durán, N. \& Lima Filho, J.L. 2011. Quality Attributes of Cupuaçu Juice in Response to Treatment with Crude Enzyme Extract Produced by Aspergillus japonicus 586. Enzyme Research 2011:1-6.

Teixeira, M.F.S., Lima Filho, J.L. \& Durán, N. 2000. Carbon Sources Effect on Pectinases Production from Aspergillus japonicus 586. Brazilian Journal of Microbiology 31: 286-290.

Tsukagoshi, N., Kobayashi, T. \& Kato, M. 2001. Regulation of the amylolytic and (hemi) cellulolytic genes in aspergilli. The Journal of General and Applied Microbiology 47: 1-19.

Wakiyama, M., Yoshihara, K., Hayashi, S. \& Ohta, K. 2008. Purification and properties of an extracellular $\beta$-xylosidase from Aspergillus japonicus and sequence analysis of the encoding gene. Journal of Bioscience and Bioengineering 106:398-404. 